\title{
Erratum to: On the semilocal convergence of the Hally method using recurrent functions
}

\author{
Ioannis K. Argyros • Saïd Hilout
}

Received: 5 April 2010 / Published online: 8 September 2011

(C) Korean Society for Computational and Applied Mathematics 2011

\section{Erratum to: J Appl Math Comput \\ DOI 10.1007/s12190-010-0431-6}

The name of Yeol Je Cho has been removed with a permission from the main author because he is an inappropriate person as a coauthor.

The correct version is: "Authors: Ioannis K. Argyros and Saïd Hilout".

The online version of the original article can be found under doi:10.1007/s12190-010-0431-6.

I.K. Argyros ( $\varangle)$

Department of Mathematics Sciences, Cameron University, Lawton, OK 73505, USA

e-mail: iargyros@cameron.edu

S. Hilout

Laboratoire de Mathématiques et Applications, Poitiers University, Bd. Pierre et Marie Curie, Téléport 2, B.P. 30179, 86962 Futuroscope Chasseneuil Cedex, France

e-mail: said.hilout@math.univ-poitiers.fr 